\section{SURFING SCIENTIFIC OUTPUT INDEXED IN THE WEB OF SCIENCE AND SCOPUS (1967-2017)}

\author{
PRODUÇÃO CIENTÍFICA DO SURFE INDEXADA NA WEB OF SCIENCE \\ E SCOPUS (1967-2017)
}

PRODUCCIÓN CIENTÍFICA DE SURFING INDEXADA EN LA WEB OF

SCIENCE Y SCOPUS (1967-2017)

Mikel Pérez-Gutiérrez*, Carlos Cobo-Corrales*

\section{Keywords:}

Bibliometrics.

Sports.

Scientific

Publication

Indicators.

\section{Palavras chave:} Bibliometria Esportes. Indicadores de Produção Científica.

Palabras clave: Bibliometría. Deportes. Indicadores de Producción Científica.

\begin{abstract}
The aim of this study was to carry out a bibliometric analysis of the surfing scientific output indexed in the Web of Science and Scopus until 2017 focused on productivity, subjects and collaboration patterns. A total of 318 documents published from 1967 to 2017 were discovered. Medical Sciences was the most represented field and the percentage of collaboration achieved $69.18 \%$. Only Australian institutions were represented within the top ten authors. Although surfing has become an emerging research field, it appears to be a rare case within Sport Sciences due to the leading role of Australian institutions.
\end{abstract}

Resumo: $O$ objetivo deste trabalho foi desenvolver uma análise bibliométrica da produção científica do surfe indexada na Web of Science e Scopus até 2017 centrada na produtividade, matérias e padrões de colaboração. Descobriram-se um total de 318 documentos publicados de 1967 até 2017. Ciências médicas foi o campo mais representado e a percentagem de colaboração foi de $69,18 \%$. Nos dez autores mais importantes só se acharam representadas instituições australianas. Embora o surfe tenha se tornado uma área de investigação emergente, parece ser um sujeito excepcional nas Ciências do Esporte devido ao papel dominante das instituições australianas.

Resumen: El objetivo de este trabajo fue desarrollar un análisis bibliométrico de la producción científica de surfing indexada en la Web of Science y Scopus hasta 2017 centrado en la productividad, materias y patrones de colaboración. Se descubrieron un total de 318 documentos publicados entre 1967 y 2017. Las Ciencias Médicas fueron el área más representada y el porcentaje de colaboración fue de $69.18 \%$. Dentro de los diez autores más importantes solo se encontraron representadas instituciones australianas. Aunque el surfing se ha convertido en un área de investigación emergente, parece ser un caso excepcional dentro de las Ciencias del Deporte debido al papel dominante de las instituciones australianas.
*University of Cantabria. España. E-mail: mikel.perez@unican.es; carlos.cobo@unican.es

Recebido em: 04-07-2019 Aprovado em: 05-02-2020 Publicado em: 11-03-2020 (c) (i) () Licence 


\section{INTRODUCTION}

Surfing boom has been dated back in the 1960s (BOOTH, 2007; KAMPION, 1997; WESTWICK; NEUSHUL, 2013) and, from that time onwards, it has experienced an important development and expansion as a social, cultural, economic and sporting activity. Socially, surfing has "gone from an exotic tropical pastime to a mainstream lifestyle practiced by millions of people around the world and envied by millions more" (WESTWICK; NEUSHUL, 2013, p. 313-314), with an estimation at between 17 and 35 million surfers globally (SURFERTODAY, 2018; WESTWICK; NEUSHUL, 2013).

From its cultural perspective, surfing has permeated other spheres of life, such as fashion, cinema or advertising. Surf wear is available in any mall around the world, surf film festivals are hosted everywhere reflecting the ongoing expansion of surfing, and different brands, consumer and food products are keen to bond their business image with surfing by means of sponsorship (KAMPION, 1997; WESTWICK; NEUSHUL, 2013).

Economically, surfing is a market sector including surfboards, wetsuits, accessories, magazines, sponsors, manufacturers, websites, wave pools, broadcasting and tourism, among others. Its global impact has been calculated in US\$50 billion each year (MCGREGOR; WILLS, 2016). As a sport, surfing has been promoted and strengthened by the International Surfing Association (ISA) and the World Surf League (WSL). The WSL has created an annual championship tour for professional surfers (WORLD SURF LEAGUE, 2018a), while the ISA is the governing authority for surfing recognised by the International Olympic Committee (IOC), comprising 104 national federations (INTERNATIONAL SURFING ASSOCIATION, 2018a) and responsible for including surfing within the Tokyo 2020 programme (INTERNATIONAL SURFING ASSOCIATION, 2018c).

Thus, surfing has evolved from an ancient pastime and cult to a professional sport (KAMPION, 1997; WESTWICK; NEUSHUL, 2013), fitting each person's interests and needs and being currently practiced as a recreational or leisure activity, a form of meditation, a lifestyle, an obsession, a religion, a competitive sport and/or a professional career (BUCKLEY, 2002; LAZAROW; MILLER; BLACKWELL, 2008). Surfing expansion and its different perspectives have also triggered scholars' interest for studying its several dimensions. Recently, scholars have approached surfing from sociology (GUIBERT; ARAB, 2017; LISAHUNTER, 2018), history (BOOTH, 2016; ESPARZA, 2016), pedagogy (BRASIL et al., 2016; RYNNE, 2016) or engineering (NESSLER; FRAZEE; NEWCOMER, 2018; SAKELLARIOU; RANA; JENKINS, 2017), to name a few.

Some reviews were also carried out for analyzing the surfing literature for coastal management (SCARFE; HEALY; RENNIE, 2009), discovering the genesis of a new research topic such as surf tourism (MARTIN; ASSENOV, 2012), studying surfer's myelopathy disease (FREEDMAN et al., 2016) and summarizing the different protocols for measuring performance (FARLEY; ABBISS; SHEPPARD, 2017). Moreover, a bibliographic review for analyzing the surfing output published from 2000 
to 2011 was performed, focusing on the total amount of documents, the journals distributing them as well as the main themes explored (BRASIL; RAMOS; GODA, 2013). However, this work mainly performed a bibliographic review of surfing literature, presenting some bibliometric indicators regarding its productivity. Therefore, the aim of the present study is to carry out a bibliometric analysis of the surfing scientific output indexed in the Web of Science and Scopus until 2017, focusing on productivity, topics and collaboration aspects, depicting the development of surfing research along time, assessing its strengths and weaknesses and determining the communication patterns among its scholars.

\section{METHODOLOGY}

Surfing article or review documents published up to and including 2017 in Scopus and the Web of Science (Science Citation Index Expanded, Social Sciences Citation Index and Arts \& Humanities Citation Index) were included in the present study. Surfing was defined as those sport activities with competition and recognised by the ISA. Thus, bodyboarding, kneeboard, longboard, shortboard, standup paddle (SUP) racing and surfing and tandem surfing (INTERNATIONAL SURFING ASSOCIATION, 2018a) were considered as the object of study. Other wave riding activities on any type of waves such as big waves surfing or bodysurfing, as well as on flat water using wave riding equipment such as wakesurfing were excluded since their competition is not governed by the ISA. Documents focused on surfing as well as including surfing activities or practitioners among their sample were selected. Article and review documents were only selected as the current main documents for the dissemination of research.

\subsection{DATA RETRIEVAL}

Data mining was performed on July 2018. The advanced search tool was used both in Scopus and the Web of Science databases. A search string was created including the different surfing activities considered as object of study and limiting the type of documents to article or review. Since the term "surf" is also used in other research areas such as Computer or Environmental Sciences for referring to surfing the internet or ocean, coastal and marine studies respectively, the term "sport" was included for reducing noise in data mining. In Scopus, the search string was the following:

(TITLE-ABS-KEY (surf OR surfing OR bodyboard OR longboard OR kneeboard OR standup OR stand-up OR paddleboard OR sup) AND TITLE-ABS-KEY (sport) ) AND (LIMIT-TO (DOCTYPE, "ar") OR LIMIT-TO (DOCTYPE , "re" ) )

Science Citation Index Expanded (SCI-EXPANDED), Social Sciences Citation Index (SSCl) and Arts \& Humanities Citation Index (A\&HCl), pertaining to the core collection of the Web of Science, were selected. Time span was set for including all years (1900-2018), following the recommendations presented by Thomson Reuters (2009). The search string was the following: 
(TS=(surf OR surfing OR bodyboard OR longboard OR kneeboard OR standup OR stand-up OR paddleboard OR sup) AND TS=(sport )) AND DOCUMENT TYPES: (Article OR Review)

After excluding those documents published in 2018, a total of 833 results were found in both databases. Then, results were exported to Endnote X 6 reference manager programme, saving the full record and cited references of each document from the Web of Science and the citation information, bibliographic information, abstract and keywords from Scopus. Duplicate references were removed, descending total results to 636. Document's title, abstract and keywords were independently checked by two researchers for considering its final inclusion regarding its topic. A third researcher was consulted when discrepancies appeared. Before data analysis, author's name was standardised for avoiding different spellings.

\subsection{DATA ANALYSIS}

Data analysis was focused on the bibliometric analysis of productivity, topics and collaboration patterns (LÓPEZ LÓPEZ, 1996). In relation to productivity, documents were distributed by year, decade and surfing activity according to those recognised by the ISA (INTERNATIONAL SURFING ASSOCIATION, 2018a). Those documents studying surfing as a whole or without paying attention to one or more surfing activities in particular were classified as "General". The amount and percentage of documents, authors, institutions and countries per decade were also analyzed. In relation to topics, documents were classified by fields of science and technology following the UNESCO nomenclature (SIMPLE KNOWLEDGE ORGANIZATION SYSTEM, 2018) and distributed by decade.

Finally, the amount of single-authored articles (SA), multi-authored articles (MA), mean of authors per article and percentage of collaboration $(\% \mathrm{C})$ were calculated and distributed per decade for analyzing the collaboration patterns. Percentage of collaboration $(\% \mathrm{C})$ was calculated using the formula given by Valenciano Valcárcel et al. (2010), being: \%C = MA/SA+MA. Moreover, number of papers, signatures, collaborators and collaboration index were also calculated for top ten most productive authors. Current institutional affiliation of these authors was also included.

\section{RESULTS}

A total of 318 documents relating to surfing have been published from 1967 to 2017 in Scopus and the Web of Science. As shown in Figure 1, this scientific output shows an irregular but progressive rise along time, existing several gaps in which no documents were published such as 1968-1976, 1979-1981, 1983, 1985 and 1994. The most productive years were 2016 and 2015 with the publication of 38 and 37 documents respectively. 
Figure 1 - Distribution of documents indexed in the Web of Science and Scopus by year.

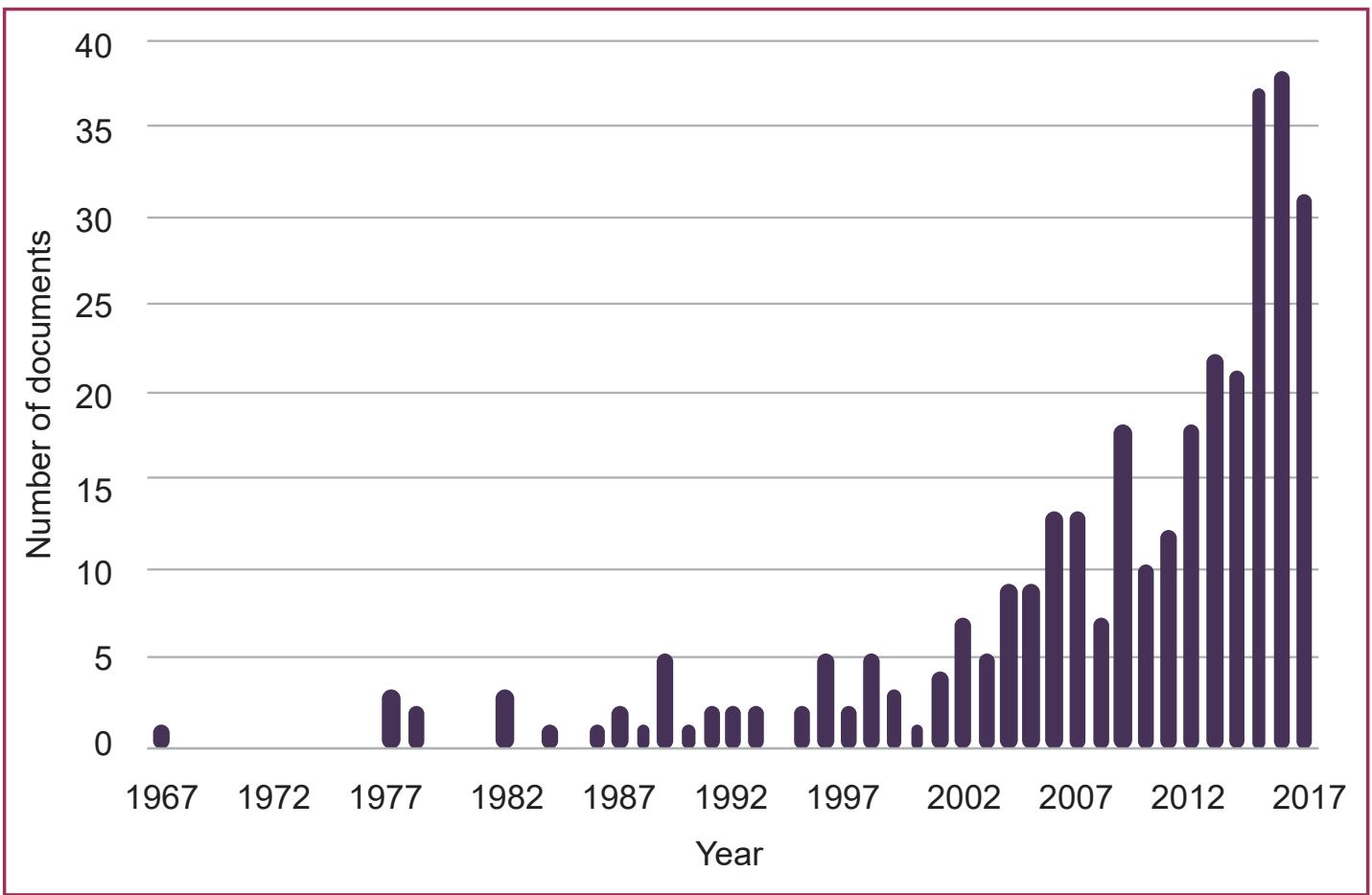

Source: prepared by authors.

Most of the documents were focused on surfing without referring to any specific activity (96.54\% of total) (Table 1). The first documents dedicated to bodyboard and SUP were published in the 1990 s and the first decade of the $21^{\text {st }}$ century, respectively.

Table 1- Frequency and percentage of documents distributed per decade and activity.

\begin{tabular}{|c|c|c|c|c|c|c|c|c|c|c|c|c|c|c|}
\hline \multirow{2}{*}{ Decade } & \multicolumn{2}{|c|}{1960} & \multicolumn{2}{|c|}{1970} & \multicolumn{2}{|c|}{1980} & \multicolumn{2}{|c|}{1990} & \multicolumn{2}{|c|}{2000} & \multicolumn{2}{|c|}{2010} & \multicolumn{2}{|c|}{ Total } \\
\hline & $\mathbf{n}$ & $\%$ & $\mathbf{n}$ & $\%$ & $\mathbf{n}$ & $\%$ & $\mathbf{n}$ & $\%$ & $\mathbf{n}$ & $\%$ & $\mathbf{n}$ & $\%$ & $\mathbf{n}$ & $\%$ \\
\hline Bodyboard & & & & & & & 1 & 0.31 & 2 & 0.63 & 2 & 0.63 & 5 & 1.57 \\
\hline SUP & & & & & & & & & 1 & 0.31 & 5 & 1.57 & 6 & 1.89 \\
\hline General & 1 & 0.31 & 5 & 1.57 & 13 & 4.09 & 23 & 7.23 & 83 & 26.10 & 182 & 57.23 & 307 & 96.54 \\
\hline
\end{tabular}

As shown in Table 2, surfing scientific output has been mainly published from 2000 onwards, with $59.43 \%$ of total documents published during the last decade. The amount of authors, institutions and countries involved shows an increasing development along time.

This scientific output is distributed in 13 different fields of science and technology, being Medical Sciences, Life Sciences and Sociology the most represented ones (Table 3). These fields show an increasing number of documents per decade, but most of them published from 2000 onwards. On the contrary, Physics and Political Science collect only two and one document, respectively. 
Table 2 - Frequency and percentage of documents, authors, institutions and countries distributed by decade.

\begin{tabular}{|c|c|c|c|c|c|c|c|c|}
\hline \multirow{2}{*}{ Decade } & \multicolumn{2}{|c|}{ Documents } & \multicolumn{2}{|c|}{ Authors } & \multicolumn{2}{|c|}{ Institutions } & \multicolumn{2}{|c|}{ Countries } \\
\hline & $\mathbf{n}$ & $\%$ & $\mathbf{n}$ & $\%$ & $\mathbf{n}$ & $\%$ & $\mathbf{n}$ & $\%$ \\
\hline 1960 & 1 & 0.31 & 1 & 0.15 & 1 & 0.37 & 1 & 3.45 \\
\hline 1970 & 5 & 1.57 & 10 & 1.46 & 6 & 2.22 & 3 & 10.34 \\
\hline 1980 & 13 & 4.09 & 20 & 2.92 & 14 & 5.19 & 8 & 27.50 \\
\hline 1990 & 24 & 7.55 & 61 & 8.89 & 31 & 11.48 & 10 & 34.48 \\
\hline 2000 & 86 & 27.04 & 187 & 27.26 & 81 & 30.00 & 13 & 44.83 \\
\hline Total & 318 & 100 & 686 & 100 & 270 & 100 & 29 & 100 \\
\hline
\end{tabular}

NOTE: \%: in relation to total amount of documents (318), authors (686), institutions (270) and countries (29), respectively. Source: prepared by authors.

Table 3 - Frequency and percentage of documents distributed by field and decade.

\begin{tabular}{|c|c|c|c|c|c|c|c|c|c|c|c|c|c|c|}
\hline \multirow{2}{*}{ Fields } & \multicolumn{2}{|c|}{1960} & \multicolumn{2}{|c|}{1970} & \multicolumn{2}{|c|}{1980} & \multicolumn{2}{|c|}{1990} & \multicolumn{2}{|c|}{2000} & \multicolumn{2}{|c|}{2010} & \multicolumn{2}{|c|}{ Total } \\
\hline & $\mathrm{n}$ & $\%$ & $\mathrm{n}$ & $\%$ & $\mathrm{n}$ & $\%$ & $\mathrm{n}$ & $\%$ & $\mathrm{n}$ & $\%$ & $\mathrm{n}$ & $\%$ & $\mathrm{n}$ & $\%$ \\
\hline $\begin{array}{l}\text { Earth and Space } \\
\text { Sciences }\end{array}$ & & & & & & & 1 & 0.31 & 1 & 0.31 & 3 & 0.94 & 5 & 1.57 \\
\hline Economic Sciences & & & & & & & 3 & 0.94 & 7 & 2.20 & 11 & 3.46 & 21 & 6.60 \\
\hline History & & & & & & & & & 7 & 2.20 & 14 & 4.40 & 21 & 6.60 \\
\hline Life Sciences & & & 1 & 0.31 & 2 & 0.63 & 3 & 0.94 & 7 & 2.20 & 47 & 14.78 & 60 & 18.87 \\
\hline Medical Sciences & 1 & 0.31 & 4 & 1.26 & 7 & 2.20 & 14 & 4.40 & 36 & 11.32 & 53 & 16.67 & 115 & 36.16 \\
\hline Pedagogy & & & & & & & & & 2 & 0.63 & 4 & 1.26 & 6 & 1.89 \\
\hline Philosophy & & & & & & & & & 1 & 0.31 & 2 & 0.63 & 3 & 0.94 \\
\hline Physics & & & & & & & & & 1 & 0.31 & 1 & 0.31 & 2 & 0.63 \\
\hline Political Science & & & & & & & & & & & 1 & 0.31 & 1 & 0.31 \\
\hline Psychology & & & & & 1 & 0.31 & & & 3 & 0.94 & 13 & 4.09 & 17 & 5.35 \\
\hline Sociology & & & & & 3 & 0.94 & 3 & 0.94 & 16 & 5.03 & 35 & 11.01 & 57 & 17.92 \\
\hline
\end{tabular}

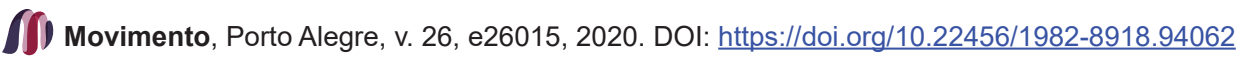


Source: prepared by authors.

Table 4 illustrates an increasing amount of single- and multi-authored articles along time. From the 1990s onwards, multi-authored articles has almost doubled the amount of single-authored articles. Regarding the collaboration patterns, the mean of authors per paper and the percentage of collaboration present an irregular development, showing their highest scores during the last decade.

Table 4 - Distribution of the amount of single-authored articles, multi-authored articles, mean of authors per article and percentage of collaboration per decade.

\begin{tabular}{ccccc}
\hline Decade & $\begin{array}{c}\text { Single-authored } \\
\text { papers }\end{array}$ & $\begin{array}{c}\text { Multi-authored } \\
\text { papers }\end{array}$ & Mean authors/paper & $\begin{array}{c}\text { \% of } \\
\text { collaboration }\end{array}$ \\
\hline $\mathbf{1 9 6 0}$ & 1 & & 1 & 0 \\
1970 & 2 & 3 & 2 & 60 \\
1980 & 8 & 5 & 1.69 & 38.46 \\
1990 & 8 & 16 & 2.58 & 66.67 \\
$\mathbf{2 0 0 0}$ & 34 & 52 & 2.45 & 60.47 \\
$\mathbf{2 0 1 0}$ & 45 & 144 & 3.26 & 76.19 \\
\hline Total & 98 & 220 & 2.16 & 69.18 \\
\hline
\end{tabular}

Source: prepared by authors.

The collaboration patterns and affiliation of the top ten most productive authors are presented in Table 5. Sheppard is the most productive author with 18 papers while Nimphius obtains the highest collaboration index (7.36). The amount of collaborators ranges from eight to 32 authors. Moreover, only Australian institutions are represented within this top ten.

Table 5 - Top ten most productive authors ( $\geq 6$ papers), with their current institutional affiliations and collaboration patterns

\begin{tabular}{|c|c|c|c|c|c|}
\hline Author & Pap. & Sig. & $\begin{array}{l}\text { Collab. } \\
\text { index }\end{array}$ & Collab. & Curr. Inst. Affl. \\
\hline $\begin{array}{c}\text { J.M. } \\
\text { Sheppard }\end{array}$ & 18 & 118 & 6.56 & 32 & $\begin{array}{l}\text { Hurley Surfing Australia High Performance } \\
\text { Centre; Edith Cowan University (Australia) }\end{array}$ \\
\hline O.R.L. Farley & 13 & 84 & 6.46 & 16 & $\begin{array}{l}\text { Hurley Surfing Australia High Performance } \\
\text { Centre; Edith Cowan University (Australia) }\end{array}$ \\
\hline $\begin{array}{l}\text { L.E. } \\
\text { Lundgren }\end{array}$ & 12 & 86 & 7.17 & 17 & $\begin{array}{l}\text { Hurley Surfing Australia High Performance } \\
\text { Centre; Edith Cowan University (Australia) }\end{array}$ \\
\hline T.T. Tran & 12 & 88 & 7.33 & 20 & $\begin{array}{l}\text { Hurley Surfing Australia High Performance } \\
\text { Centre; Edith Cowan University (Australia) }\end{array}$ \\
\hline J.L. Secomb & 11 & 78 & 7.09 & 15 & $\begin{array}{l}\text { Hurley Surfing Australia High Performance } \\
\text { Centre; Edith Cowan University (Australia) }\end{array}$ \\
\hline S. Nimphius & 11 & 81 & 7.36 & 18 & $\begin{array}{l}\text { Hurley Surfing Australia High Performance } \\
\text { Centre; Edith Cowan University (Australia) }\end{array}$ \\
\hline M. Climstein & 8 & 35 & 4.38 & 8 & Bond University (Australia) \\
\hline R.U. Newton & 8 & 64 & 8 & 16 & Edith Cowan University (Australia) \\
\hline W.A. Hing & 8 & 35 & 4.38 & 9 & Bond University (Australia) \\
\hline J.W. Furness & 6 & 29 & 4.83 & 9 & Bond University (Australia) \\
\hline
\end{tabular}

NOTE: Pap: papers; Sig: signatures; Collab. index: collaboration index; Collab.: collaborators; Curr. Inst. Affl.: cur- 
rent institutional affiliation.

Source: prepared by authors.

\section{DISCUSSION}

Surfing scientific output, indexed in the Web of Science and Scopus, collected 318 documents published irregularly but progressively from 1967 to 2017, showing a constant production from 1994 onwards. In relation to surfing, some reviews were performed for presenting an overview of its documents (BRASIL; RAMOS; GODA, 2013) and studying its relationship with coastal management (SCARFE; HEALY; RENNIE 2009) and tourism (MARTIN; ASSENOV, 2012), but they presented methodological discrepancies in comparison with our work. These works included different type of documents such as conference proceedings, Master's and PhD's theses, books or reports (MARTIN; ASSENOV, 2012; SCARFE; HEALY; RENNIE, 2009), considered only documents published in English (MARTIN; ASSENOV, 2012; SCARFE; HEALY; RENNIE, 2009), or English, Portuguese or Spanish and checked other databases such as Science Direct, Scielo or Google Scholar (BRASIL; RAMOS; GODA, 2013). However, their results could be compared. Scarfe, Healy and Rennie. (2009) found 162 documents published irregularly from 1971 to 2007 but most of them from 1998 onwards, while research on surf tourism started in 1997 with a total of 156 documents published until $2011,60 \%$ of them collected during the 20072011 period and reflecting the new and emerging character of this field of knowledge (MARTIN; ASSENOV, 2012). On the other hand, Brasil, Ramos and Goda. (2013) found 150 surfing documents published from 2000 to 2011, showing a progressive rise along time but specially during the last five years analysed. The specificity of their object of study explains the different amount of documents retrieved in comparison with our results, although they included other type of documents. Nevertheless, it seems surfing has been capturing scholars' attention from different disciplines and they have started publishing their works mainly during the $21^{\text {st }}$ century.

Our results should be also compared with studies using a similar methodology and focusing on specific sport activities. The study carried out by Peset et al. (2013) collected 383 judo documents indexed in the Web of Science and published progressively from 1956 to 2010, but especially from 1995 onwards. In the same way, Palazón, Ortega and García-Angulo (2015) also checked the Web of Science from 2005 to 2014 for retrieving futsal scientific production and found 81 articles, most of them published from 2010 onwards. Considering the Web of Science and MEDLINE, Prieto, Gómez, and Sampaio (2015) discovered 373 articles focused on handball and published from 1961 to 2012, but increasing progressively from 1995 onwards. Finally, regarding taekwondo scientific output, Pérez-Gutiérrez et al. (2017) developed a bibliometric analysis in the Web of Science and found 340 articles published from 1988 to 2016, with 10 or more articles per year from 2006 onwards. Despite these studies only considered the Web of Science (PALAZÓN: ORTEGA; GARCÍA-ANGULO ., 2015; PÉREZ-GUTIÉRREZ et al., 2017; PESET et al., 2013) or other databases (PRIETO; GÓMEZ: SAMPAIO., 2015) and the amount of documents retrieved were considerably different, they are depicting the starting date and evolution of scientific research in these sports. Without considering futsal, 
research on judo, handball, taekwondo and surfing started during the second half of the $20^{\text {th }}$ century and presented an important rise in their output near the turn of the century, being in accordance with the evolution of Sport Sciences output in SouthAmerica (ANDRADE et al., 2013).

Moreover, surfing research was probably triggered by its boom happened in the 1960s, attracting scholars' attention and reflecting its cultural expansion to movies, magazines, TV shows, language, fashion, literature, lifestyle and music (KAMPION, 1997; WESTWICK; NEUSHUL, 2013) as well as the increasing amount of practitioners. From that time onwards, surfing output has constantly increased, doubling its size every 10 years from 1995, corroborating the exponential growth of science stated by Derek J.S. Price (LÓPEZ LÓPEZ, 1996; PRICE, 1986).

Surfing research has been mainly approached by scholars from a general perspective and only few studies were specifically dedicated to bodyboarding and SUP surfing (Table 1). Similarities among the different surfing activities recognised by the ISA and the possible application and generalization of the results obtained by these studies may be understood as the main causes for the high percentage of studies $(96.55 \%)$ which are not dedicated to a specific surfing activity. Although kneeboard, longboard, shortboard or tandem surfing were not represented within the analyzed documents, their results and conclusions may be cautiously applied to these activities. Scholars have analyzed surfing activities as a whole, despite their practice (WARSHAW, 2003), hazards (OMORI et al., 2015), sport (INTERNATIONAL SURFING ASSOCIATION, 2018b) and culture (MIZUNO, 2018; WAITT; FRAZER, 2012), are different. Brasil, Ramos and Godal. (2013) mentioned surfing, as an sporting practice, has become a physical educators' new working and studying area as well as a widespread leisure activity, involving an increasing amount of professionals for meeting market demands, such as coaches, instructors, tour managers or accommodation staff, for example. The social and economic impact of surfing, with millions of practitioners and an estimation of US $\$ 50$ billion to global economic activity each year (MCGREGOR; WILLS, 2016), are probably the main causes explaining the rising interest of scholars for studying it.

The increasing number of authors, institutions and countries involved in surfing research (Table 2) is reflecting the ongoing development of this scientific topic and community. Along time, the amount of documents, authors and institutions has doubled those obtained in the previous decade respectively, while the involvement of different countries to the study of surfing has increased irregularly. The boom of surfing research should be dated to the $21^{\text {st }}$ century and specifically to the last decade, despite there exists a two-year gap for completing this decade. The inclusion of surfing within the Tokyo 2020 Olympic Games programme, for bringing "more youthful and vibrant activities into the Olympic programme" (TOKYO 2020 ORGANISING COMMITTEE, 2018), will probably trigger the amount of both competitive and recreational practitioners. The social relevance of this mega event, considering half of world's population watched at least some coverage of Rio 2016, six million tickets were sold (INTERNATIONAL OLYMPIC COMMITTEE, 2016) and a revenue of USD nine billion was estimated (SETTIMI, 2016), will promote surfing to a greater 
extent, and consequently a rise in the number of articles should be expected at the end of the present decade.

In relation to other sports scientific output, some differences are observed. Prieto, Gómez and Sampaio. (2015) found a total of 782 authors pertaining to 31 different countries involved in handball research, while Pérez-Gutiérrez et al. (2015) discovered 476 authors from 35 countries represented in taekwondo output. Surfing is currently practiced worldwide (WESTWICK; NEUSHUL, 2013) but the development of its research mainly during the $21^{\text {st }}$ century may explain the lower number of scholars and countries involved in this output in relation to handball and taekwondo research, respectively.

Due to surfing's historical expansion and social development it has been classified as a postmodern sport (STEDMAN, 1997), showing a "[...] dialectic between the aesthetic orientation of the counter culture on the one hand, and the professionalization and sportization of surfing on the other" (STRANGER, 2001, p. 70), particularly in Australia (BOOTH, 1994). The characteristics exhibited by postmodernism, specifically the breakdown of the grand narratives, the loss of consensus about the belief in science and the social life guided by the pleasure principle, relativism and privatism (REAL, 1966), and its application to the sports world, featuring a focus on fun, recreation and pleasure (BODET, 2009), should explain the distance between surfing and the research and academic fields in comparison to other modern sports such as soccer, basketball or tennis, with a longer history and/or competitive presence.

Regarding the different approaches for analyzing surfing, 13 different fields were represented, being Medical Sciences the most represented followed by Life Sciences and Sociology (Table 3). These three fields collected more than $70 \%$ of total production, focusing on the study of injuries and diseases associated to surfing (FREEDMAN et al., 2016; JUBBAL et al., 2017), the analysis of surfers' performance (COYNE et al., 2017; FORSYTH et al., 2017) and several sociological aspects such as gender boundaries and surfer's identity (COMLEY, 2016; USHER, 2017), respectively. The relevance of these fields is representing the two popular images of surfing, from a sporting and performance approach to a leisure and/or spiritual practice (STRANGER, 2001). Furthermore, in the case of the Medical and Life Sciences, the emergence of pro surfing with the establishment of an international pro tour in 1976 governed by the International Professional Surfers firstly and then by the Association of Surfing Professionals probably triggered scholars' interest on physiological and/or injuries-related aspects of surfing (WORLD SURF LEAGUE, 2018b). As complementary fields, Economic Sciences, History and Psychology gathered approximately $18 \%$, reflecting the development of emerging research areas focused on surfing economic impact (LOPES; BICUDO, 2017; PONTING; O'BRIEN, 2015), its origins or expansion (ALVES; MELO, 2017; ESPARZA, 2016) and surfer's perceptions or attitudes concerning their practice (AMRHEIN; BARKHOFF; HEIBY ., 2016; CADDICK; SMITH, 2017).

In the same way, the predominance of Life and Medical Sciences within the Sport Sciences field of knowledge has been corroborated in the scientific 
production about futsal (PALAZÓN; ORTEGA; GARCÍA-ANGULO 2015), handball (PRIETO; GÓMEZ; SAMPAIO, 2015) and taekwondo (PÉREZ-GUTIÉRREZ et al., 2017), published in South-America (ANDRADE et al., 2013) and Chile (PÉREZGUTIÉRREZ; LAGOS-HERNÁNDEZ; IZQUIERDO-MACÓN, 2016; PÉREZGUTIÉRREZ; COBO-CORRALES; IZQUIERDO-MACÓN, 2018), within the Spanish Sport Sciences journals (VALENCIANO VALCÁRCEL; DEVÍS DEVIIS; BELTRÁN CARRILLO, 2008) and the Sport Sciences journals indexed in the Journal Citation Reports (TSIGILIS et al., 2010). Therefore, our findings are in accordance with these studies.

Considering research and international collaboration are likely to increase the productivity and quality of documents respectively (KYVIK; REYMERT, 2017), the collaborative research exhibited in surfing output (Table 4 ) could be expected. A similar pattern has been observed in futsal, handball and taekwondo production, with $60 \%$ of documents signed by four to six authors (PALAZÓN; ORTEGA; GARCÍAANGULO, 2015) and a mean of authors per article over three (PÉREZ-GUTIÉRREZ et al., 2017; PRIETO; GÓMEZ; SAMPAIO, 2015), respectively.

In relation to the most productive authors and their collaboration (Table 5), a high collaborative research group pertaining to two Australian institutions leads surfing scientific output, exemplifying the scientific knowledge transfer between Edith Cowan University and the performance center of Australian surfing organization (SURFING AUSTRALIA, 2019). In contrast, Pérez-Gutiérrez et al. (2017) found a group of five scholars from different countries leading taekwondo research, while Peset et al. (2013) discovered three authors leading judo production affiliated to Brazilian, Polish and French institutions. Moreover, the collaboration index shown in these studies was lower than that observed in surfing. The structure and characteristics of the spearhead of surfing, taekwondo and judo scientific community is clearly different despite they are worldwide sport practices, collecting a similar total output.

Considering results shown in Table 2 and Table 5, top ten authors, representing $1.5 \%$ of total amount of authors, published 107 papers, representing $33 \%$ of total output. This situation is reflecting Price's law, indicating a group of prolific authors account for half the publications in a certain field (DIODATO, 2012). Furthermore, the amount of collaborators and the collaboration index of the top ten most productive authors (Table 5) as well as the increasing number of multi-authored articles and mean of authors per article (Table 4) are depicting a key feature associated with modern "Big Science" (PRICE, 1986), that is, collaborative work.

Surfing research is centralized and boosted by an Australian single national research network in which authors collaborate among them, most of the time. The socio-cultural context surrounding Australian surfing's culture and identity, being classified as a national iconic sport (BOSTON CONSULTING GROUP; AUSTRALIAN SPORTS COMMISSION, 2017; MCGLOIN, 2005; WARSHAW, 2010) or a "national pastime" (MOORE, 2010, p. 4) and the surfer as the "prototype modern Australian" (WESTWICK; NEUSHUL, 2013, p. 149) could explain this situation. The Australian government's efforts for promoting and strengthening surfing as a sport (AUSTRALIAN SPORTS COMMISSION; SURFING AUSTRALIA, 2018), including the expansion of 
its performance center with the final aim of winning gold in Tokyo 2020 (SURFING AUSTRALIA, 2017) corroborates the importance of surfing for them, permeating the academic field and stimulating studies about this topic. Surfing research appears to be a rare case due to the leading role of Australian institutions since within Sport Sciences, international collaboration strongly intensified from 2000/2001 to 2010/2011, showing Australia a faster growth than other countries (WANG; THIJS; GLÄNZEL, 2015).

\section{CONCLUSION}

The present study showed surfing scientific output collected 318 documents, a considerable amount in comparison with the production found in other surfing, judo, futsal, handball or taekwondo studies. They were exponentially published from 1967 to 2017 , but mainly during the $21^{\text {st }}$ century, confirming the exponential growth of science. This production was focused on surfing activities in general, involving an increasing number of authors, institutions and countries along time. Regarding collaboration, surfing output depicted the features of modern Big Science with an increasing collaboration work along time and a global mean of 2.16 authors per article. Top ten authors showed different patterns of collaboration, but all of them are affiliated to Australian institutions, representing an unusual situation of Price's law in which the most prolific authors are from the same country and institutions.

In summary, from an ancient pastime and cult, surfing has evolved to a professional sport, leisure activity, lifestyle, form of meditation/religion and/or a profession, permeating different social, cultural, economic, sporting and academic spheres. This situation together with the considerable amount of documents published mainly from 1994 onwards and the development of surf tourism research are reflecting the emerging character of surfing scientific output. The predominance of the Medical, Life and Social Sciences, the collaborative work among authors and the leading role of Australian scholars and institutions have depicted both the strengths and weaknesses of surfing research. Nevertheless, the present study has some limitations that should be pointed out. Despite two of the main international databases were consulted for data mining, future studies should check other databases such as Eric, Pubmed, SportDiscus or PsycINFO as well as other languages and type of documents for achieving a wider overview of surfing research. When performing an historical analysis of scientific production, data retrieval depends partially on the efforts and decisions made by journals' and databases' managers respectively for providing availability and accessibility to that production. Scholars should consider this situation for understanding and discussing their results.

Future studies should carry out a content analysis of the topics explored in surfing scientific production for obtaining a deeper understanding. The analysis of the social, cultural, economic and/or political forces boosting surfing research in Australia would be useful for understanding the leading role of this country. The analysis of the scientific production of sports such as sport climbing or skateboarding, also included within Tokyo 2020 programme, should be carried out for determining the impact of this worldwide event within the academic field and discovering similar patterns of publication and/or collaboration. 


\section{REFERENCES}

ALVES, Vladimir Zamorano; MELO, Victor Andrade. Surfing and counter culture in the 1970s Rio de Janeiro. Revista Brasileira de Ciencias do Esporte, v. 39, n. 1, p. 2-9, 2017.

AMRHEIN, Michael; BARKHOFF, Harald; HEIBY, Elaine M. Spirituality, depression, and anxiety among ocean surfers. Journal of Clinical Sport Psychology, v. 10, n. 2, p. 155171, 2016.

ANDRADE, David Cristobal et al. Bibliometric analysis of South American research in sports science from 1970 to 2012. Motriz, v. 19, n. 4, p. 783-791, 2013.

AUSTRALIAN SPORTS COMMISSION; SURFING AUSTRALIA. The turning point: case study 2018. Disponível em: https://www.ausport.gov.au/_data/assets/pdf file/0006/580911/P and SS 34122 Surfing Case Study AUG15.pdf. Acesso em: 03 out. 2018.

BODET, Guillaume. Sport Participation and Consumption and Post-Modern Society: From Apollo to Dionysus? Loisir et Société / Society and Leisure, v. 32, n. 2, p. 223-241, 2009.

BOSTON CONSULTING GROUP; AUSTRALIAN SPORTS COMMISSION.

Intergenerational Review of Australian Sport 2017. 2017. Disponível em: https://www. clearinghouseforsport.gov.au/_data/assets/pdf_file/0009/752733/Intergenerational_Review of Australian Sport 2017.pdf. Acesso em: 03 out. 2018.

BOOTH, Douglas. Surfing '60s: A case study in the history of pleasure and discipline. Australian Historical Studies, v. 26, n. 103, p. 262-279, 1994.

BOOTH, Douglas. Surfing. In: BOOTH, Douglas; THORPE, Holly. Berkshire Encyclopedia of Extreme Sports. London: Berkshire, 2007. p.317-323.

BOOTH, Douglas. The Bondi Surfer: An Underdeveloped History. Journal of Sport History, v. 43, n. 3, p. 272-289, 2016.

BRASIL, Vinicius Zeilmann; RAMOS, Valmor; GODA, Ciro. A produção científica sobre surf: uma análise a partir das publicações entre 2000-2011. Pensar a Prática, v. 16, n. 3, p. 619955, 2013.

BRASIL, Vinicius Zeilmann et al. As açoes pedagógicas para a intervençao do treinador de surf. Movimento, v. 22, n. 2, p. 403-416, 2016.

BUCKLEY, Ralf. Surf Tourism and Sustainable Development in Indo-Pacific Islands. I. The Industry and the Islands. Journal of Sustainable Tourism, v. 10, n. 5, p. 405-424, 2002.

CADDICK, Nick; SMITH, Brett. Combat surfers: a narrative study of veterans, surfing, and war trauma. Movimento, v. 23, n. 1, p. 25-38, 2017.

COMLEY, Cassie. "We have to establish our territory": how women surfers 'carve out' gendered spaces within surfing. Sport in Society, v. 19, n. 8-9, p. 1289-1298, 2016.

COYNE, Joseph O. C. et al. Maximal strength training improves surfboard sprint and endurance paddling performance in competitive and recreational surfers. Journal of Strength and Conditioning Research, v. 31, n. 1, p. 244-253, 2017.

DIODATO, Virgil. Dictionary of bibliometrics. New York: Routledge, 2012.

ESPARZA, Daniel. Towards a Theory of Surfing Expansion: The Beginnings of Surfing in 
Spain as a Case Study. RICYDE. Revista Internacional de Ciencias del Deporte, v. 12, n. 44, p. 199-215, 2016.

FARLEY, Oliver R. L.; ABBISS, Chris R.; SHEPPARD, Jeremy M. Performance analysis of surfing: A review. Journal of Strength and Conditioning Research, v. 31, n. 1, p. 260-271, 2017.

FORSYTH, James R. et al. Analysis of scoring of maneuvers performed in elite men's professional surfing competitions. International Journal of Sports Physiology and Performance, v. 12, n. 9, p. 1243-1248, 2017.

FREEDMAN, Brett A. et al. Surfer's myelopathy: A rare form of spinal cord infarction in novice surfers: A systematic review. Neurosurgery, v. 78, n. 5, p. 602-611, 2016.

GUIBERT, Christophe; ARAB, Chadia. Being a Female Surfer in Morocco: The Norms and Social Uses of the Beach. Tourism, Culture and Communication, v. 17, n. 3, p. 159-172, 2017.

INTERNATIONAL OLYMPIC COMMITTEE. How do we know that Rio 2016 was a success. 2016. Disponível em: https://www.olympic.org/news/how-do-we-know-that-rio2016-was-a-success. Acesso em: 11 mar.2019.

INTERNATIONAL SURFING ASSOCIATION. About ISA. 2018a. Disponível em: https:// www.isasurf.org/isa-info/isal . Acesso em: 08 out. 2018.

INTERNATIONAL SURFING ASSOCIATION. ISA Rulebook \& Contest Administration Manual. 2018b. Disponível em: http://www.isasurf.org/wp-content/uploads/ downloads/2018/08/ISA-Rulebook_-15-Aug-2018.pdf . Acesso em: 08 out.2018.

INTERNATIONAL SURFING ASSOCIATION. Riding the wave to Olympic inclusion. 2018c. Disponível em: http://www.isasurf.org/riding-the-wave-to-olympic-inclusion/. Acesso em: 08 out. 2018.

JUBBAL, Kevin T. et al. Analysis of surfing injuries presenting in the acute trauma setting. Annals of Plastic Surgery, v. 78, n. 5, p. S233-S237, 2017.

KAMPION, Drew. Stocked: A History of Surf Culture. Koln: Evergreen, 1997.

KYVIK, Svein; REYMERT, Ingvild. Research collaboration in groups and networks: differences across academic fields. Scientometrics, v. 113, n. 2, p. 951-967, 2017.

LAZAROW, Neil; MILLER, Marc; BLACKWELL, Boyd. The Value of Recreational Surfing to Society. Tourism in Marine Environments, v. 5, n. 2-3, p. 145-158, 2008.

LISAHUNTER. Surfing, sex, genders and sexualities. New York: Routledge, 2018.

LOPES, João T.; BICUDO, Pedro. Surfing tourism plan: Madeira Island case study. European Journal of Tourism Research, v. 16, p. 45-56, jan. 2017.

LÓPEZ LÓPEZ, Pedro. Introducción a la bibliometría. Valencia: Promolibro, 1996.

MARTIN, Steven Andrew; ASSENOV, llian. The genesis of a new body of sport tourism literature: a systematic review of surf tourism research (1997-2011). Journal of Sport \& Tourism, v. 17, n. 4, p. 257-287, 2012.

MCGLOIN, Colleen. Surfing Nation(s) - Surfing Country(s). 2005. 356 f. Dissertação (PhD) - School of Social Sciences, Media and Communications, University of Wollongong, Wollongong, 2005. 
MCGREGOR, Thomas; WILLS, Samuel. Natural Assets: Surfing a wave of economic growth. Oxford: Oxford Centre for the Analysis of Resource Rich Economies, University of Oxford, 2016.

MIZUNO, Erri. Multiple marginalization?: Representation and experience of bodyboarding in Japan. In: LISAHUNTER. Surfing, Sex, Genders and Sexualities. Abingdon: Routledge, 2018. p.71-90.

MOORE, Michael Scott. Sweetness and Blood: How Surfing Spread from Hawaii and California to the Rest of the World, with Some Unexpected Results. New York: Rodale, 2010.

NESSLER, Jeff A.; FRAZEE, Tayler; NEWCOMER, Sean C. The effect of foil on paddling efficiency in a short surfboard. Sports Engineering, v. 21, n. 1, p. 11-19, 2018.

OMORI, Kazuhiko et al. Analysis of patients with bodyboarding injuries transported by physician-staffed emergency helicopter. Journal of Emergencies, Trauma, and Shock, v. 8, n. 1, p. 39-42, 2015.

PALAZÓN, María Angles; ORTEGA, Enrique; GARCÍA-ANGULO, Antonio. Análisis bibliométrico de la producción científica en el fútbol sala. SporTK: Revista Euroamericana de Ciencias del Deporte, v. 4, n. 2, p. 19-24, 2015.

PÉREZ-GUTIÉRREZ, Mikel; COBO-CORRALES, Carlos; IZQUIERDO-MACÓN, Eugenio. Chilean sport sciences scientific production indexed in the Web of Science (1981-2016). Motriz, v. 24, n. 1, p. e1018148, 2018.

PÉREZ-GUTIÉRREZ, Mikel; LAGOS-HERNÁNDEZ, Roberto Iván; IZQUIERDO-MACÓN, Eugenio. Sport Sciences' scientific production published in Chile (1912-2014): a bibliometric approach. Movimento, v. 22, n. 4, p. 1121-1136, 2016.

PÉREZ-GUTIÉRREZ, Mikel et al. Bibliometric analysis of taekwondo articles published in the Web of Science (1989-2013). IDO Movement for Culture. Journal of Martial Arts Anthropology, v. 15, n. 3, p. 8-21, 2015.

PÉREZ-GUTIÉRREZ, Mikel et al. Taekwondo scientific production published on the Web of Science (1988-2016): collaboration and topics. Movimento, v. 23, n. 4, p. 1325-1340, 2017.

PESET, Fernanda et al. Scientific literature analysis of Judo in Web of Science. Archives of Budo, v. 9, n. 2, p. 81-91, 2013.

PONTING, Jess; O'BRIEN, Danny. Regulating "Nirvana": Sustainable surf tourism in a climate of increasing regulation. Sport Management Review, v. 18, n. 1, p. 99-110, 2015.

PRICE, Derek J. de Solla. Little Science, Big Science... and Beyond. New York: Columbia Universit, 1986.

PRIETO, Jaime; GÓMEZ, Miguel Angel; SAMPAIO, Jaime. Revisión bibliométrica de la producción científica en balonmano. Cuadernos de Psicología del Deporte, v. 15, n. 3, p. 145-154, 2015.

REAL, Michael R. Postmodern Aesthetics: MTV, David Lynch, and the Olympics. In: REAL, Michael R. Exploring Media Cuture: A Guide. California: SAGE, 1966. p. 237-266.

RYNNE, Steven. Exploring the pedagogical possibilities of Indigenous sport-for-development programmes using a socio-personal approach. Sport, Education and Society, v. 21, n. 4, p. 605-622, 2016.

SURFING AUSTRALIA. Annual Report. 2017. Disponível em: https://d30ei0jhgxjdue. 
cloudfront.net/uploads/ckeditor/attachment file/data/1240/uploads 2F151054558552197|xtb5hhj-bd8b296d119e573a694c6cfc87d232f8 2F2017\%2BSA\%2BAnnual\%2BReport\%2 BREF.pdf Acesso em: 27 jun. 2019.

SURFING AUSTRALIA. The Surfing Australia High Performance Centre. 2019. Disponível em: https://www.surfingaustraliahpc.com/ . Acesso em: 27 jun. 2019.

SAKELLARIOU, Konstantinos; RANA, Zeeshan A.; JENKINS, Karl W. Optimisation of the surfboard fin shape using computational fluid dynamics and genetic algorithms. Proceedings of the Institution of Mechanical Engineers Part P. Journal of Sports Engineering and Technology, v. 231, n. 4, p. 344-354, 2017.

SCARFE, Bradley E.; HEALY, Terry R.; RENNIE, Hamish G. Research-Based Surfing Literature for Coastal Management and the Science of Surfing - A Review. Journal of Coastal Research, v. 25, n. 3, p. 539-557, 2009.

SETTIMI, Christina. The 2016 Rio Summer Olympics: By The Numbers. 2016. Disponível em: https://www.forbes.com/sites/christinasettimi/2016/08/05/the-2016-summer-olympics-inrio-by-the-numbers/. Acesso em: 11 mar. 2019.

SIMPLE KNOWLEDGE ORGANIZATION SYSTEM. UNESCO nomenclature for fields of science and technology. 2018. Disponível em: http://skos.um.es/unesco6/. Acesso em: 08 ago. 2018.

STEDMAN, L. From Gidget to Gonad Man: surfers, feminists and postmodernisation. The Australian and New Zealand Journal of Sociology, v. 33, n. 1, p. 75-90, 1997.

STRANGER, Mark James Anthony. Risk-taking and Postmodernity: Commodification \& the Ecstatic in Leisure Lifestyles. The Case of Surfing. 2001. 314 f. Dissertação (PhD), University of Tasmania, Tasmania, 2001.

SURFERTODAY. How many surfers are there in the world?, 2018. Disponível em: https:// www.surfertoday.com/surfing/14228-how-many-surfers-are-there-in-the-world . Acesso em: 08 out. 2018.

THOMSON REUTERS. Web of Science $\mathbf{8 . 0}$ Workshop: Science Citation Index Expanded, Social Sciences Citation Index, Arts \& Humanities Citation Index. Toronto: Thomson Reuters, 2009.

TOKYO 2020 ORGANISING COMMITTEE. Olympic Sports: Surfing. 2018. Disponível em: https:/tokyo2020.org/en/games/sport/olympic/surfing/ . Acesso em: 11 mar. 2019.

TSIGILIS, Nikolaos et al. Impact factors of the sport sciences journals: Current trends, relative positions, and temporal stability. European Journal of Sport Science, v. 10, n. 2, p. 81-90, 2010.

USHER, Lindsay E. "Foreign Locals": Transnationalism, Expatriates, and Surfer Identity in Costa Rica. Journal of Sport and Social Issues, v. 41, n. 3, p. 212-238, 2017.

VALENCIANO VALCÁRCEL, Javier; DEVÍS DEVÍS, José; BELTRÁN CARRILLO, Vicente Javier. La investigación y las revistas científicas de la actividad física y el deporte en España. Fuentes: Revista de la Facultad de Ciencias de la Educación, n. 8, p. 209-218, 2008.

VALENCIANO VALCÁRCEL, Javier et al. La colaboración científica en el campo de las Ciencias de la Actividad Física y el Deporte en España. Revista Española de Documentación Científica, v. 33, n. 1, p. 90-105, 2010. 
WAITT, Gordon; FRAZER, Ryan. "The vibe" and "the glide": surfing through the voices of longboarders. Journal of Australian Studies, v. 36, n. 3, p. 327-343, 2012.

WANG, Lei; THIJS, Bart; GLÄNZEL, Wolfgang. Characteristics of international collaboration in sport sciences publications and its influence on citation impact. Scientometrics, v. 105, p. 843-862, 2015.

WARSHAW, Matt. The Encyclopedia of Surfing. Orlando: Harcourt, 2003.

WARSHAW, Matt. The History of Surfing. San Francisco: Chronicle Books, 2010.

WESTWICK, Peter; NEUSHUL, Peter. The World in the Curl: An Unconventional History of Surfing. New York: Crown, 2013.

WORLD SURF LEAGUE. About. 2018a. Disponível em: http://www.worldsurfleague.com/ pages/about. Acesso em: 08 out. 2018.

WORLD SURF LEAGUE. History. 2018b. Disponível em: http://www.worldsurfleague.com/ pages/history. Acesso em: 08 out. 2018. 